\title{
"Reversed polarization" of Na/K-ATPase-a sign of inverted transport in the human endolymphatic sac: a super-resolution structured illumination microscopy (SR-SIM) study
}

\author{
Charlotta Kämpfe Nordström ${ }^{1}$ (I) $\cdot$ Niklas Danckwardt-Lillieström $^{1} \cdot$ Wei Liu ${ }^{1} \cdot$ Helge Rask-Andersen $^{1}$
}

Received: 21 May 2019 / Accepted: 15 September 2019 / Published online: 12 November 2019

(C) The Author(s) 2020

\begin{abstract}
The human endolymphatic sac (ES) is believed to regulate inner ear fluid homeostasis and to be associated with Meniere's disease (MD). We analyzed the ion transport protein sodium/potassium-ATPase (Na/K-ATPase) and its isoforms in the human ES using super-resolution structured illumination microscopy (SR-SIM). Human vestibular aqueducts were collected during translabyrinthine vestibular schwannoma surgery after obtaining ethical permission. Antibodies against various isoforms of $\mathrm{Na} / \mathrm{K}$ ATPase and additional solute-transporting proteins, believed to be essential for ion and fluid transport, were used for immunohistochemistry. A population of epithelial cells of the human ES strongly expressed $\mathrm{Na} / \mathrm{K}$-ATPase $\alpha 1, \beta 1$, and $\beta 3$ subunit isoforms in either the lateral/basolateral or apical plasma membrane domains. The $\beta 1$ isoform was expressed in the lateral/ basolateral plasma membranes in mostly large cylindrical cells, while $\beta 3$ and $\alpha 1$ both were expressed with "reversed polarity" in the apical cell membrane in lower epithelial cells. The heterogeneous expression of Na/K-ATPase subunits substantiates earlier notions that the ES is a dynamic structure where epithelial cells show inverted epithelial transport. Dual absorption and secretion processes may regulate and maintain inner ear fluid homeostasis. These findings may shed new light on the etiology of endolymphatic hydrops and MD.
\end{abstract}

Keywords Human $\cdot$ Endolymphatic sac $\cdot \mathrm{Na} / \mathrm{K}$-ATPase $\cdot$ Reversed polarity $\cdot \mathrm{SIM}$

\begin{tabular}{lll} 
Abbreviations & & NKCC2 \\
ED & Endolymphatic duct & \\
ES & Endolymphatic sac & VA \\
E & Endolymph & ENaC \\
EDTA & Ethylene-diamine-tetra-acetic acid & MD \\
Na/K-ATPase & Sodium/potassium-ATPase & TJ \\
& & SR-SIM \\
& \\
\hline Charlotta Kämpfe Nordström & MRC \\
\multicolumn{2}{c}{ lottalaloo@hotmail.com; } \\
charlotta.kampfe.nordstrom@akademiska.se & RRC \\
$\square$ Wei Liu & PBS \\
\multicolumn{2}{l}{ lwoo24@gmail.com } & BSA \\
\end{tabular}

Niklas Danckwardt-Lillieström niklas.danckwardt.lilliestrom@akademiska.se

Helge Rask-Andersen

helge.rask-andersen@surgsci.uu.se

1 Department of Surgical Sciences, Section of Otolaryngology, Uppsala University Hospital, SE-751 85 Uppsala, Sweden

$\begin{array}{ll}\text { NKCC2 } & \begin{array}{l}\text { Sodium/potassium/chloride } \\ \text { cotransporter } 2\end{array} \\ \text { VA } & \text { Vestibular aqueduct } \\ \text { ENaC } & \text { Epithelial sodium channel } \\ \text { MD } & \text { Meniere's disease } \\ \text { TJ } & \text { Tight junctions } \\ \text { SR-SIM } & \text { Super-resolution structured } \\ & \text { illumination microscopy } \\ \text { MRC } & \text { Mitochondria-rich cell } \\ \text { RRC } & \text { Ribosome-rich cell } \\ \text { PBS } & \text { Phosphate buffered saline } \\ \text { BSA } & \text { Bovine serum albumin } \\ \text { VA } & \text { Vestibular aqueduct } \\ \text { CF } & \text { Cerebrospinal fluid }\end{array}$

\section{Introduction}

The function of the human endolymphatic sac (ES) remains an enigma. This intriguing part of the inner ear is believed to be 
involved in several activities, such as endolymph resorption, pressure regulation, and immune reactions (Lundquist et al. 1964; Rask-Andersen et al. 1991; Jansson et al. 1992; Salt and DeMott 2000). The ES develops early (Raft et al. 2014), suggesting a role in the maturation of the inner ear fluid compartments.

The ES is linked to Meniere's disease (MD), as interruption from the rest of the inner ear leads to endolymphatic hydrops, an equivalent of MD (Kimura and Schuknecht 1965; Kimura 1967). Pendrin, an anion exchanger encoded by the SLC26A4 gene, may play a crucial role in the development of the inner ear fluid spaces (Honda et al. 2017). A lack of pendrin reduces endolymph resorption and leads to congenital enlargement of the ES and vestibular aqueduct (EVA) which is associated with childhood deafness (Park 2003).

Human ES contains a heterogeneous population of epithelial cells, while the rodent ES contains two distinguishable cell types, namely, the mitochondria-rich cells (MRCs) and ribosome-rich cells (RRCs) (Friberg et al. 1984a; Rask-Andersen et al. 1991; Dahlmann and von Düring 1995; Qvortrup et al. 1999; Peters et al. 2001). In the guinea pig, these cells are represented by the "light" cells (Lundquist et al. 1964) and in man by the cylindrical cells (Friberg et al. 1985). The MRCs are believed to absorb sodium and fluid from the ES lumen, while the RRCs may be involved in secretion and immune activity (Erwall et al. 1988). MRCs express SLC26A4, $\mathrm{Na}^{+}$-permeable channels, and $\mathrm{Na} / \mathrm{K}$-ATPase (Miyashita et al. 2007). Na/K-ATPase is localized in the basolateral cell membrane of the MCRs and is thought to expel sodium ions into the extracellular space along with fluid. Sodium absorption may be driven by the Na/K-ATPase pump in combination with selective ion channels and a positive ES potential (ESP) in the lumen (Amano et al. 1983; Mori et al. 2017)

Studies of the human ES are motivated because of species differences. Recently, several reports on ion transporters in the human ES were presented using cDNA micro-array, reverse transcription polymerase chain reaction (RT-PCR), and immunohistochemistry (Kumagami et al. 2004; Kim et al. 2009; Kakigi et al. 2009; Lee et al. 2012; Møller et al. 2015).

We used super-resolution structured illumination microscopy (SR-SIM) to analyze the $\mathrm{Na} / \mathrm{K}$-ATPase protein and its isoforms in the human ES. The technique allows immune histochemical investigation of proteins with high resolution beyond the diffraction (Hell and Wichmann 1994; Gustafsson et al. 2008). The goal was to expand our knowledge of endolymph resorption in the human ES and its role in MD. An SR-SIM study of $\mathrm{Na} / \mathrm{K}$ ATPase activity in the human cochlea was recently presented (Liu et al. 2017).

\section{Material and methods}

\section{The human vestibular aqueduct}

The technique used to collect the ES was recently described by the authors (Kämpfe Nordström et al. 2018). After obtaining ethical permission, human ESs were collected during trans-labyrinthine vestibular schwannoma removal. The ES was drilled out with a thin rim of surrounding bone to preserve the epithelium. The endolymphatic duct ED and the ES overlying the sigmoid sinus (SS) were not analyzed (Fig. 1). The tissue was fixed in 4\% paraformaldehyde diluted with $0.1 \mathrm{M}$ phosphate buffered saline (PBS) at $\mathrm{pH} 7.4$ in the operating room. After $24 \mathrm{~h}$, the specimens were washed in PBS and then placed in $0.5 \mathrm{M}$ Na-ethylene-diamine-tetraacetic acid (EDTA) solution (Medicago AB, Uppsala, Sweden) buffered in PBS to $\mathrm{pH} 7.2$ for decalcification. The decalcification process lasted for approximately 3 weeks. The ESs were embedded in Tissue-Tek O.C.T.TM compound (Sakura ${ }^{\circledR}$ Finetek, Torrance, CA, USA) in preparation for freezing. They were rapidly frozen and sectioned at 8 $10 \mu \mathrm{m}$ using a cryostat microtome (Leica CM 1860, Leica Microsystems GmbH, Wetzlar, Germany). The frozen sections were collected onto glass slides (SuperFrost ${ }^{\circledR}$ Plus, Menzel-Gläzer, Braunschweig, Germany) and stored below $-70{ }^{\circ} \mathrm{C}$ before immunohistochemistry was conducted.

\section{Antibodies and immunohistochemistry}

Table 1 shows the series of antibodies used in the present study. The specificity of the antibodies was proven by the following:

- $\mathrm{Na} / \mathrm{K}$-ATPase $\beta 1$ : western blot (Wyckelsma et al. 2017)

- $\mathrm{Na} / \mathrm{K}$-ATPase $\beta 2$ : western blot (www.alomone.com)

- $\mathrm{Na} / \mathrm{K}$-ATPase $\beta 3$ : western blot (www.abbexa.com)

- $\mathrm{Na} / \mathrm{K}$-ATPase $\alpha 1^{\prime}$ : western blot (Ren et al. 2019)

- $\mathrm{Na} / \mathrm{K}$-ATPase $\alpha 1$ ": western blot (Yamashita et al. 2018)

- $\mathrm{Na} / \mathrm{K}$-ATPase $\alpha 2$ : western blot (www.avivasysbio.com)

- $\mathrm{Na} / \mathrm{K}$-ATPase $\alpha 3$ : western blot (Ivakine et al. 2013)

- Carbonic anhydrase II: western blot (www. atlasantibodies.com)

- NKCC2: western blot (www.avivasysbio.com)

- Mineralocorticoid receptor': western blot (Bordin et al. 2016)

- Mineralocorticoid receptor": western blot (www. thermofisher.com)

- Vasopressin receptor type 2: western blot (www.abbexa. com)

- ENaC: western blot (Li et al. 2017)

- Aquaporin 2: western blot (Yang et al. 2015)

- Aquaporin 4: western blot (Ruiz-Ederra et al. 2007)

- Pendrin: western blot (Jia et al. 2016) 
Fig. $13 \mathrm{D}$ reconstruction from a micro-CT of a left human inner ear mold from the Uppsala archival temporal bone collection showing the vestibular aqueduct (VA) (red) together with cochlea (C) and semicircular canal and facial nerve canal (yellow). The VA runs from the medial side of the vestibule posteriorly to the posterior cranial fossa and contains the endolymphatic duct and sac. The sac consists of an intraosseous part located inside the temporal bone and an extraosseous part located in the dura near the sigmoid sinus (SS). The external aperture of the VA is located at interrupted bold lines. Inset: The sac has a proximal (1), intermediate (2), and distal part (3). P: internal acoustic porous

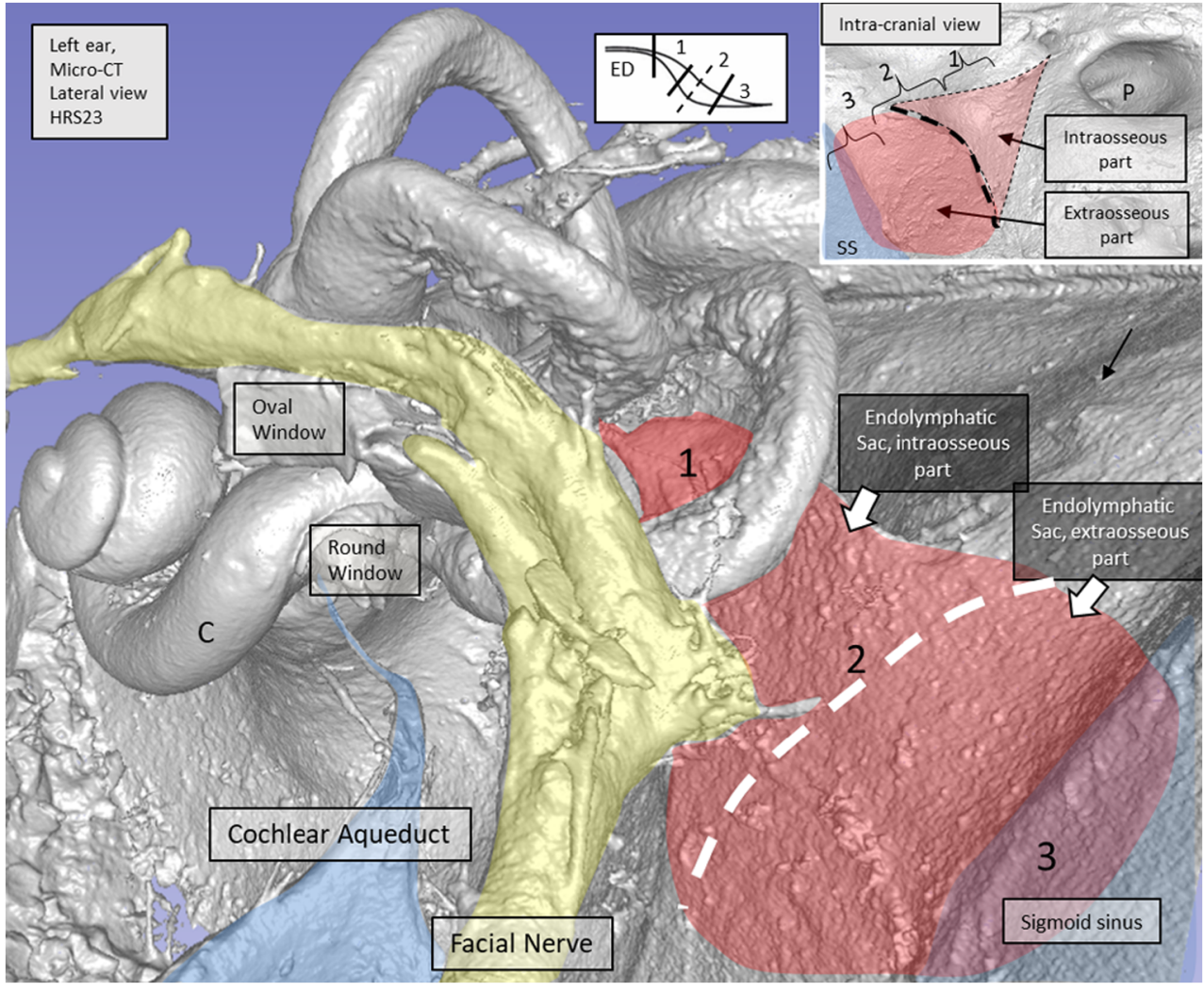

- NKCC1: western blot (Hampel et al. 2018)

- NCC: western blot (www.thermofisher.com)

The immunohistochemistry procedures performed on the sections have been described in previous publications (Liu et al. 2009, 2017). Briefly, the slide-mounted sections were incubated with an antibody solution under a humidified atmosphere at $4{ }^{\circ} \mathrm{C}$ for $20 \mathrm{~h}$. After rinsing with PBS three times for 5 min each, the sections were incubated with secondary antibodies conjugated to Alexa Fluor 488 and 555 (Molecular Probes, Carlsbad, CA, USA) for $2 \mathrm{~h}$ at room temperature. The primary and secondary antibodies were diluted in $2 \%$ bovine serum albumin (BSA) dissolved in PBS. The sections were then counter-stained with the nuclear stain DAPI (4', 6diamidino-2-phenylindole dihydro-chloride) for $5 \mathrm{~min}$, rinsed with PBS $(3 \times 5 \mathrm{~min})$, and mounted with ProLong® Gold Antifade Mountant (Thermo Fisher Scientific, Waltham, MA, USA) as well as the specified cover glass required for optically matching the microscope objectives. Primary and secondary antibody controls and labeling controls were used to exclude endogenous labeling or reaction products (Burry 2011). Control sections were incubated with $2 \%$ bovine serum albumin (BSA), omitting the primary antibodies. The control experiment revealed no visible staining in any structure of the inner ear sections. Both wide-field and confocal fluorescence imaging software exhibited sensitive fluorescent saturation indications, thereby avoiding overexposure. In addition, archival sections of guinea pig (Harlan Sprague Dawley Inc., Indianapolis, Indiana, USA) choroid plexus were analyzed according to methods described by Liu et al. (Kämpfe Nordström et al. 2018).

\section{Imaging and photography}

Microscopy was performed in an inverted fluorescence microscope (Nikon TE2000; Nikon, Tokyo, Japan) with three filters (for emission spectra maxima at 358,461 , and $555 \mathrm{~nm}$ ). The microscope is equipped with a three-channel laser emission system for confocal microscopy. SR-SIM was performed using a Zeiss Elyra S.1 SIM system and a $63 \times / 1.4$ oil PlanApochromat objective (Zeiss, Oberkochen, Germany), a sCMOS camera (PCO Edge), and the ZEN 2012 software (Zeiss). Multicolor SR-SIM imaging was achieved with laser and filter setup: 1 st channel $-405-\mathrm{nm}$ laser excitation and BP 420-480 + LP 750 filter; 2nd channel - 488-nm laser excitation and BP 495-550 + LP750 filter; and 3rd channel-561$\mathrm{nm}$ laser excitation and BP 570-620 + LP 750 filter. Five grid rotations and five phases were used for each image plane and channel. SR-SIM images were processed with ZEN software using automatic settings and theoretical point spread function (PSF) calculations. 3D reconstruction was performed with Imaris 8.2 (Bitplane AG, Zürich, Switzerland). A lateral (X$\mathrm{Y})$ resolution of $\approx 100 \mathrm{~nm}$ and an axial $(\mathrm{Z})$ resolution of $\approx$ 
Table 1 Antibodies used in the study

\begin{tabular}{|c|c|c|c|c|c|}
\hline Antibody & Type & Dilution & Host & Catalog number & Producer \\
\hline $\mathrm{Na} / \mathrm{K}$-ATPase $\beta 1$ & Monoclonal & $1: 100$ & Mouse & MA3-930 & Thermo Fisher, Waltham, USA \\
\hline $\mathrm{Na} / \mathrm{K}$-ATPase $\beta 2$ & Polyclonal & $1: 50$ & Rabbit & ANP-012 & Alomone Labs, Jerusalem, Israel \\
\hline $\mathrm{Na} / \mathrm{K}$-ATPase $\beta 3$ & Polyclonal & $1: 200$ & Rabbit & Abx111158 & Abbexa, Cambridge, UK \\
\hline $\mathrm{Na} / \mathrm{K}$-ATPase $\alpha 1^{\prime}$ & Monoclonal & $1: 50$ & Mouse & SC 21712 & Santa Cruz Biotechnology, Dallas, USA \\
\hline $\mathrm{Na} / \mathrm{K}$-ATPase $\alpha 1^{\prime \prime}$ & Monoclonal & $1: 50$ & Mouse & NB300-146 & Novus, Littleton, USA \\
\hline $\mathrm{Na} / \mathrm{K}$-ATPase $\alpha 2$ & Polyclonal & $1: 100$ & Rabbit & OAAB03232 & Aviva Systems Biology, San Diego, USA \\
\hline $\mathrm{Na} / \mathrm{K}$-ATPase $\alpha 3$ & Monoclonal & $1: 50$ & Mouse & NB300-540 & Novus, Littleton, USA \\
\hline Carbonic anhydrase II & Polyclonal & $1: 50$ & Rabbit & HPA001550 & Atlas Antibodies, Stockholm, Sweden \\
\hline NKCC2 & Polyclonal & $1: 200$ & Rabbit & OABB01331 & Aviva Systems Biology, San Diego, USA \\
\hline Mineralocorticoid receptor' & Monoclonal & $1: 50$ & Mouse & MA1-620 & Thermo Fisher, Waltham, USA \\
\hline Mineralocorticoid receptor" & Polyclonal & $1: 200$ & Rabbit & PA5-81527 & Thermo Fisher, Waltham, USA \\
\hline Vasopressin receptor type 2 & Polyclonal & $1: 50$ & Rabbit & Abx133128 & Abbexa, Cambridge, UK \\
\hline $\mathrm{ENaC}$ & Polyclonal & $1: 100$ & Rabbit & PA1-920A & Thermo Fisher, Waltham, USA \\
\hline Aquaporin-2 & Polyclonal & $1: 50$ & Rabbit & NB110-74682 & Novus, Littleton, USA \\
\hline Aquaporin-4 & Polyclonal & $1: 50$ & Rabbit & AQP-004 & Alomone Labs, Jerusalem, Israel \\
\hline Pendrin & Polyclonal & $1: 50$ & Rabbit & NBP1-60106 & Novus, Littleton, USA \\
\hline NKCC1 & Polyclonal & $1: 100$ & Rabbit & AB59791 & Abcam, Cambridge, UK \\
\hline $\mathrm{NCC}$ & Polyclonal & $1: 100$ & Rabbit & PA5-77816 & Thermo Fisher, Waltham, USA \\
\hline
\end{tabular}

$300 \mathrm{~nm}$ is achieved (Gustafsson et al. 2008). The resolution of the SIM system in BioVis (Uppsala, Sweden) was analyzed using fluorescent beads ( $40 \mathrm{~nm}$, Zeiss) in the green channel (BP 495-550 + LP750). The resolution of the system was found to be $107 \mathrm{~nm}$ in the X-Y plane and $394 \mathrm{~nm}$ in the $Z$ plane. The principle of structured illumination microscopy is based on a wide-field technique using the moire effect of interfering fine striped patterns of excitation. This contrasts to the confocal technique using detected fluorescence light at the focal plane.

\section{Numerical analysis of staining characteristics}

As the expression of $\mathrm{Na} / \mathrm{K}$-ATPase $\beta 1$ and $\mathrm{Na} / \mathrm{K}$-ATPase $\alpha 1$ may represent two different cell types, a quantification of these subunit expressing cells was made. Five sections that were stained for $\mathrm{Na} / \mathrm{K}$-ATPase $\beta 1$ and five sections that were stained for $\mathrm{Na} / \mathrm{K}$-ATPase $\alpha 1$ were randomly chosen. Only sections where the entire ES epithelium was visible were selected. Cells were counted manually, and staining was categorized in two groups (positive staining or negative staining). A total number of 7936 cells were counted (Table 2).

\section{Results}

SR-SIM showed rich expression of $\mathrm{Na} / \mathrm{K}$-ATPase isoform subunits $\alpha 1, \beta 1$, and $\beta 3$ in the epithelium of the human ES. There was no or only sparse staining for the isoform subunits $\alpha 2, \alpha 3$, and $\beta 2 . \mathrm{Na} / \mathrm{K}$-ATPase was expressed in the basolateral cell membrane in cubic and cylindrical cells (Figs. 2, 3, and 4) and in the apical cell membrane with "reversed polarity" in cubic and low epithelial cells (Figs. 5, 6, and 7). The cylindrical cells, which are believed to represent the MRC cell in rodents (Dahlmann and von Düring 1995) strongly expressed the isoform $\beta 1$ in the basolateral cell membrane together with carbonic anhydrase (CA) (Fig. 4). A corresponding $\alpha$ subunit could not be established, but it was not $\alpha 1$. Both the intra- and extra-osseous parts of the ES expressed the isoform $\beta 1$ in the basolateral cell membranes. The cylindrical cells were mostly located in the intermediate portion of the ES (Fig. 2). Some lower or cubic cells also strongly expressed $\mathrm{Na} / \mathrm{K}$-ATPase in the basolateral plasma membrane. Some epithelial cells, particularly in the distal sac, did not express the $\beta 1$ subunit to a major extent. Quantification of cells showed that $78 \%$ of the ES epithelial cells expressed $\beta 1$ in the basolateral cell membrane. The $\alpha 1$ subunit was expressed in the apical cell membrane in $40 \%$ of the cells. At high magnification, $\mathrm{Na} / \mathrm{K}$-ATPase protein was seen to translocate from organelles near the cell nucleus to

Table 2 Evaluation of staining

\begin{tabular}{lll}
\hline $\mathrm{Na} / \mathrm{K}-\mathrm{ATPase}$ subunit & Negative & Positive \\
\hline$\beta 1$ (basolateral expression) & $22 \%$ & $78 \%$ \\
$\alpha 1 *$ (apical expression) & $60 \%$ & $40 \%$ \\
\hline
\end{tabular}

$* \alpha 1$ subunit mostly co-expressed with $\beta 3$ subunit 
Fig. 2 Immunohistochemistry of a guinea pig choroid plexus (a, b) and a human ES obtained at surgery (c). $\mathrm{Na} / \mathrm{K}$-ATPase $\alpha 1$ and $\beta 3$ subunits are expressed in the apical cell membrane (a). Framed area is magnified in $b$. The apical cell membrane (small arrow) expresses the $\alpha 1$ subunit, while the $\beta 3$ isoform is strongly expressed in the perinuclear zone (long arrow). An ES was labeled with antibodies against both $\beta 1$ and $\beta 3$ isoforms from different species (c). In the proximal part of the sac (left), the $\beta 1$ isoform was more expressed and in the basolateral cell membrane of the epithelium. In the distal part (right), the $\beta 3$ subunit was more expressed and in the apical cell membranes in the epithelium. Here, only a few cells express the $\beta 1$ isoform (inset). Left frame is magnified in Fig. 3
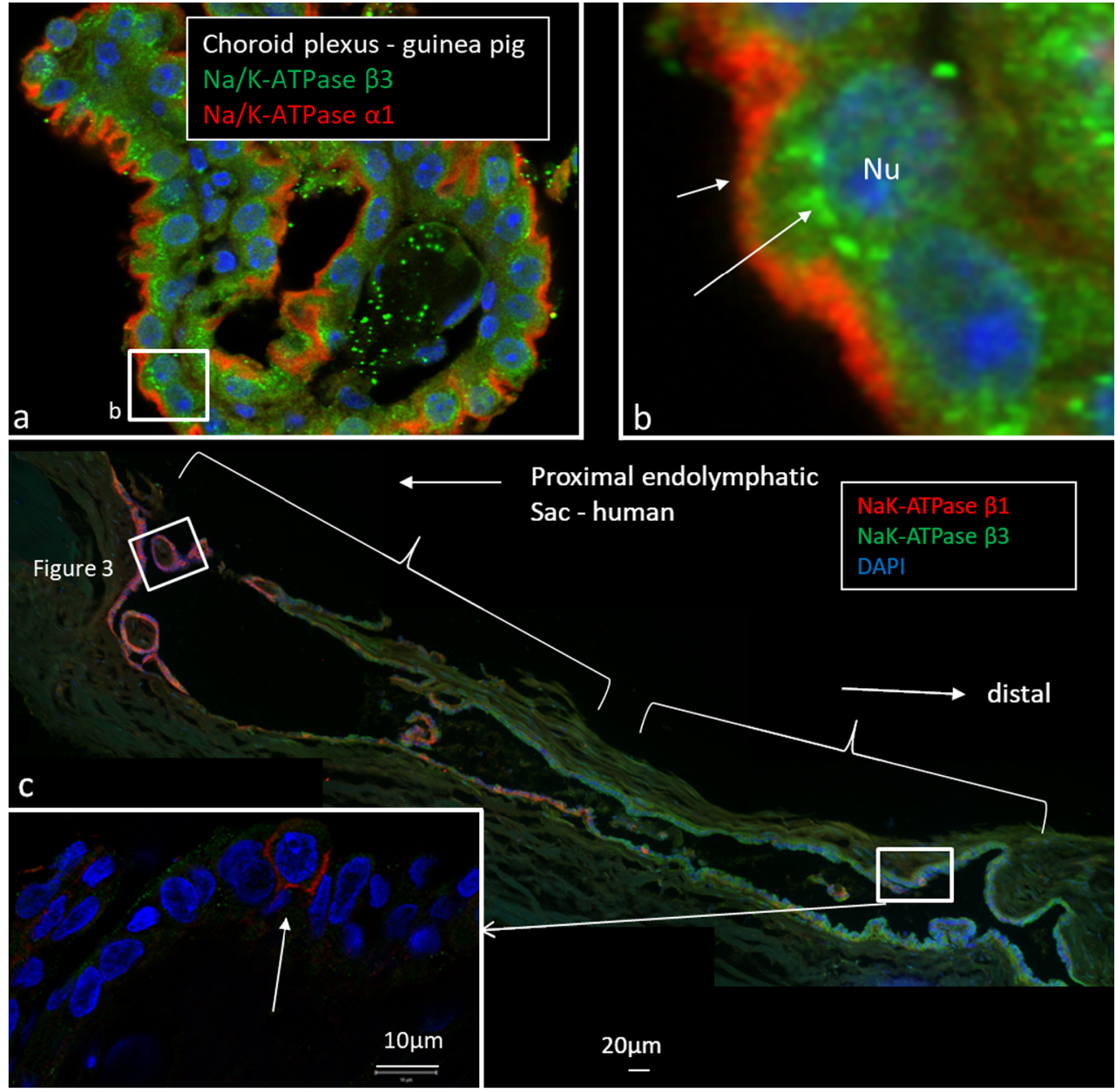

the lateral plasma membrane (Fig. 4, insets). Na/K-ATPase expression in the basolateral plasma membrane ended apically at the tight junctions. In a few cells, parts of the apical cell membrane also expressed the ion transporter (Fig. 4). The size of the $\beta 1$ aggregate was around $150 \mathrm{~nm}$ and, contrary to the CA protein, was not expressed in the cell nuclei. Some epithelial cells, which may represent the RRCs, strongly coexpressed $\beta 3$ and $\alpha 1$ isoforms in the apical cell membrane (Figs. 5, 6, and 7). These cells and also cylindrical cells expressed the amiloride-sensitive $\mathrm{Na}^{+}$channel $\mathrm{ENaC}$ as well as the thiazide-sensitive $\mathrm{Na}^{+}$channel NCC (Fig. 8d, e). Na/KATPase $\alpha 1 \beta 3$ complexes labeled selectively the apical cell membrane, and the $\alpha 1$ subunit had a size of $100-150 \mathrm{~nm}$, and the $\beta 3$ was approximately $75 \mathrm{~nm}$ (Fig. 6c, inset). The subunits appeared separately in the cell nuclei and in the juxta-nuclear cytoplasm. In some cells, $\beta 3$ was expressed in the apical cell membrane without $\alpha 1$ (Fig. 7). This was seen adjacent to cells co-expressing $\alpha 1$ and $\beta 3$ in the apical membrane (Fig. 7b, inset). Both subunits were seen in the nuclei portions facing the apical cell membrane (Fig. $6 \mathrm{~b}$ and $7 \mathrm{a}$, inset). $\mathrm{Na} / \mathrm{K}$-ATPase was occasionally expressed together with the $\mathrm{Na} / \mathrm{K} / \mathrm{Cl}$ cotransporter 2 (NKCC2) but not $\mathrm{NKCC} 1$
(Fig. 8a, c). NKCC2 was expressed diffusely in the cytoplasm and separately from $\mathrm{Na} / \mathrm{K}$-ATPase. Some epithelial cells expressed NKCC2 in the cytoplasm and cell membrane without $\mathrm{Na} / \mathrm{K}$-ATPase $\beta 1$.

Many epithelial cells in the intermediate portion expressed the mineralocorticoid receptor (MR) (Fig. 8). The MR was expressed both in the cytoplasm and cell nuclei. Several of these cells expressed $\mathrm{Na} / \mathrm{K}$-ATPase $\beta 1$ isoform (Fig. 8, inset). Pendrin and vasopressin receptor (V2) were diffusely expressed in the cytoplasm in some epithelial cells (not shown). Antibodies against the $\mathrm{Na} / \mathrm{K}$-ATPase $\alpha 1$ and $\beta 3$ isoforms were used to label (positive control) the secretory epithelium of the guinea pig choroid plexus. Both isoforms stained positive for the isoforms (Fig. 2a, b). The $\alpha 1$ expression was "polarized" and restricted to the apical plasma membrane. Positive controls also showed $\mathrm{Na} / \mathrm{K}$-ATPase $\beta 1$ and NKCC1 co-expression in marginal cells of the cochlea, but with separate expressions in the basolateral membrane in the outer sulcus (Fig. 9). Aquaporin 2 and 4 were moderately expressed in epithelial cells of the intermediate sac (not shown). 


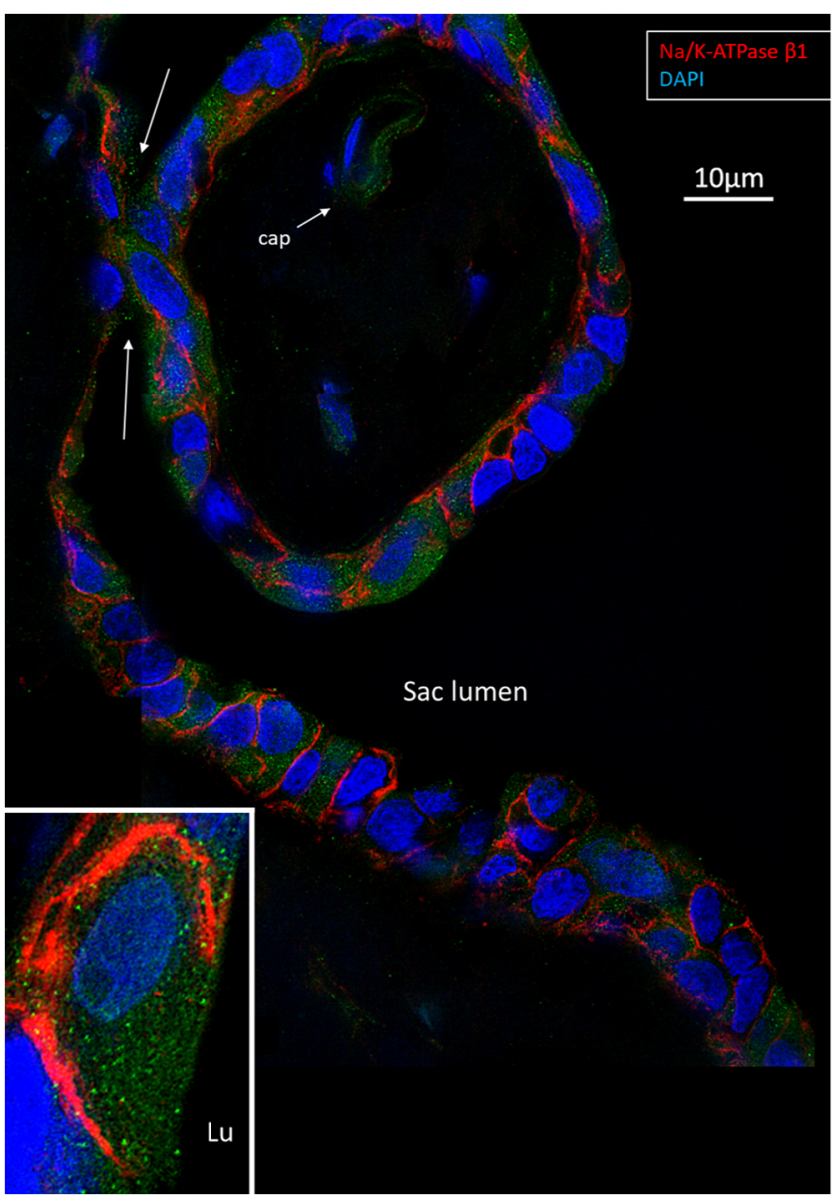

Fig. 3 Expression of $\mathrm{Na} / \mathrm{K}$-ATPase $\beta 1$ isoform (SIM, single optical section) in the epithelium of the intraosseous part of the human ES. The basolateral cell membranes strongly express the transporter protein. Arrows mark an epithelial protrusion into the sac lumen $(\mathrm{Lu})$. A capillary (cap) is seen in the loose connective tissue. Inset shows a cell expressing $\mathrm{Na} / \mathrm{K}$-ATPase at higher magnification

\section{Discussion}

This is the first study to analyze ion channels and transporters in the human ES using SR-SIM. We focused on Na/K-ATPase and its possible role in endolymph resorption. The human ES is unique compared with the rest of the inner ear because of its variable morphology and mixed cell types (Bauwens et al. 1991; Lee et al. 2012) reflecting multiple functions (BaggerSjöbäck et al. 1988). Five types of epithelial cells were earlier observed in the human ES (Bagger-Sjöbäck et al. 1988).

We found expression of $\alpha 1, \beta 1$, and $\beta 3$ isoforms in the epithelial cells of the human ES. Various $\mathrm{Na} / \mathrm{K}$-ATPase isozymes are known to have an exclusive affinity for ions serving specialized cell functions. $\mathrm{Na} / \mathrm{K}$-ATPase consists of four catalytic $\alpha$ isoforms, three regulatory $\beta$, and seven FXYD subunits with ATP hydrolysis (Crambert et al. 2000; Blanco 2005; Geering 2008; Xie et al. 2013). The $\alpha 1$ subunit is expressed in most tissues, and the $\alpha 2$ and $\alpha 3$ isoforms are expressed in skeletal muscle, neuronal, and cardiac tissues,

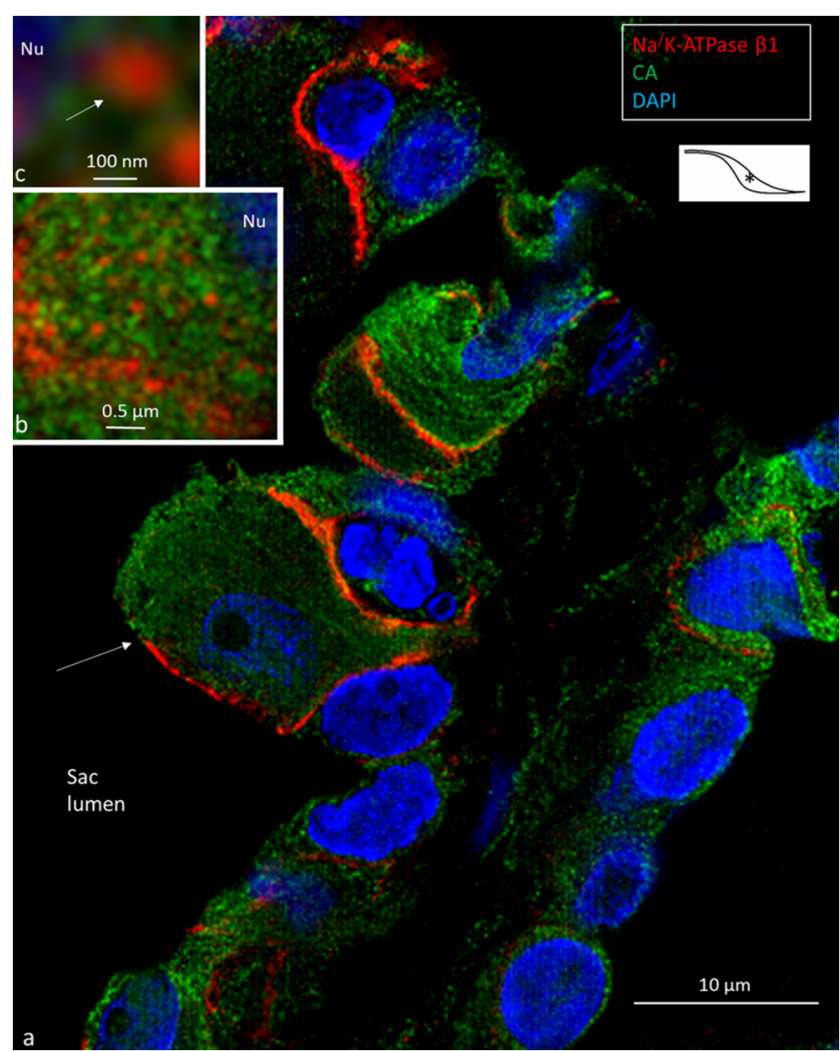

Fig. 4 Nanoscopic resolution of $\mathrm{Na} / \mathrm{K}$-ATPase $\beta 1$ isoform and $\mathrm{CA}$ expression (single optical section) in a cylindrical cell the intermediate portion of the human ES. Inset showing level of sectioning (*) of the ES. There is a strong expression of $\mathrm{Na} / \mathrm{K}$-ATPase in the lateral/basolateral cell membrane (a). A part of the apical membrane also seems to express the $\beta$ isoform (arrow). Higher magnification of protein aggregates in the cytosol bridging the space between the cell nucleus $(\mathrm{Nu})$ and the lateral plasma membrane $(b, c)$

while the $\alpha 4$ isoform is restricted to the testis. The $\alpha 1 \beta 1$ heterodimer is the exclusive $\mathrm{Na} / \mathrm{K}$-ATPase complex expressed in kidney tubules (Feraille and Dizin 2016), but any $\alpha$ isoform can be expressed with any beta (Clausen et al. 2017). The $\beta$ association is necessary for adequate folding of synthesized subunits (Hasler et al. 1998), while the FXYD proteins modulate $\mathrm{Na} / \mathrm{K}$-ATPase (Blanco 2005; Clausen et al. 2017).

$\mathrm{Na} / \mathrm{K}-\mathrm{ATPase}$ plays a crucial role in ion and fluid transportation in the inner ear that contains systems responsible for secretion of $\mathrm{K}^{+}$into endolymph and generation of the endocochlear potential. The $\alpha 1 \beta 1$ heterodimer is the predominant combination in epithelial cells to maintain ion gradients (Weber et al. 2001). In a recent study, the dense accretion of $\mathrm{Na} / \mathrm{K}$-ATPase $\alpha \beta$ heterodimer complexes was exposed in the basolateral cell membrane of the marginal cells and outer sulcus in the human cochlea (Liu et al. 2017). A strong basolateral distribution of $\mathrm{Na} / \mathrm{K}$-ATPase $\beta 1$ isoform together with apical $\mathrm{Na}^{+}$-selective channels suggests an active sodium uptake from the ES lumen with excretion into the subcellular space. The findings are consistent with earlier studies showing $\mathrm{Na} / \mathrm{K}$-ATPase in the adult ES (Yamane and Nakai 1988; 

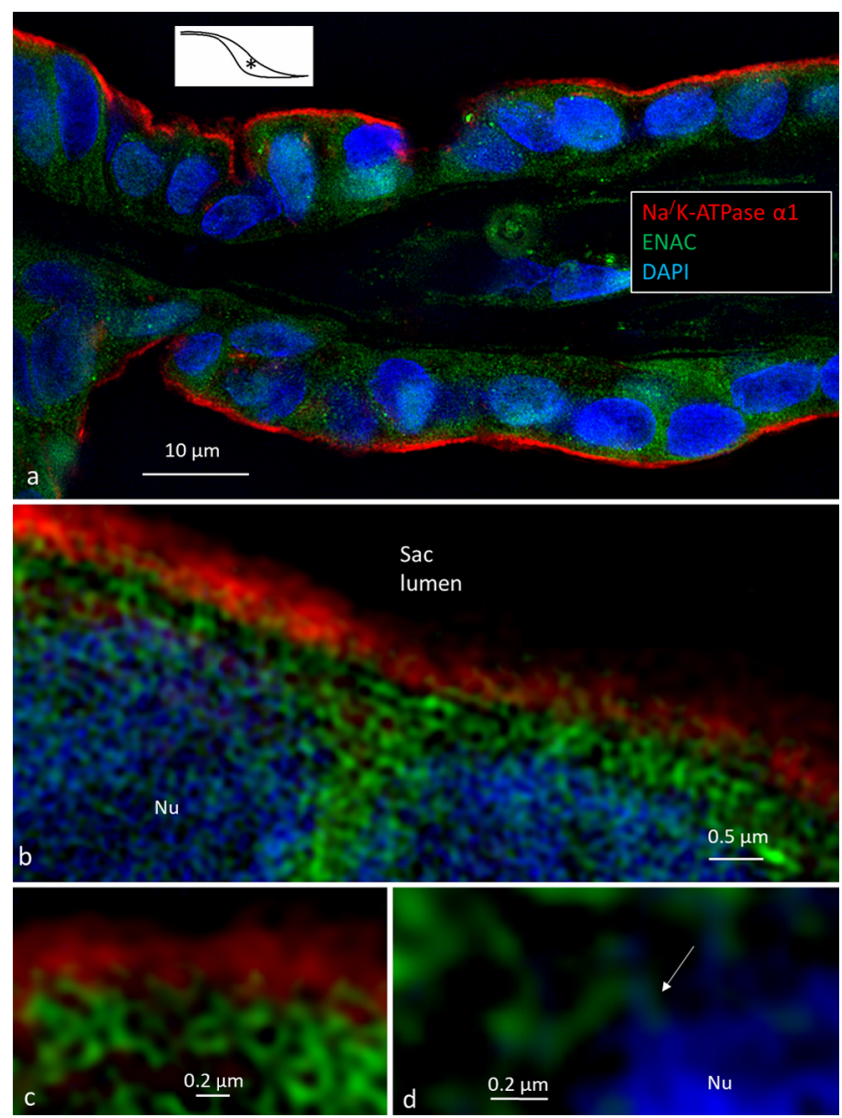

Fig. 5 SR-SIM (single optical section) of an epithelial villus in the human ES (intermediate portion). Inset showing level of sectioning (*) of the ES. Expression of $\mathrm{Na} / \mathrm{K}$-ATPase $\alpha 1$ isoform and epithelial sodium channel $(\mathrm{ENaC})$. b. Strong expression of $\mathrm{Na} / \mathrm{K}$-ATPase is localized only to the apical cell membrane. c. Nanoscopic resolution shows molecular relationship between $\mathrm{Na} / \mathrm{K}$-ATPase and ENAC in the apical cytoplasm. $d$. ENAC fluorescence at the juxta-nuclear region (arrow)

Ichimiya et al. 1994; ten Cate et al. 1994; Peters et al. 2001; Akiyama et al. 2010; Miyashita et al. 2012). ten Cate et al. (1994) found $\alpha 1$ and $\beta 2$ subunit isoforms and, to a lesser extent, the $\beta 1$ subunit in the guinea pig ES. They concluded that, since the combination is different from typical ion and fluid transporting tissues, for example, kidney and colon, it may reflect distinctive characteristics of inner ear $\mathrm{Na} / \mathrm{K}$ ATPase. Fina and Ryan (1994) examined the mRNA encoding isoforms and found only weak expression of $\mathrm{Na} / \mathrm{K}$-ATPase, limited to $\alpha 1, \beta 1$, and $\beta 2$ in the rat ES. They suggested that the ES is not a major site for ion exchange. Indirect studies of epithelial transport by the ESP (endolymphatic sac potential), recorded after injection of ouabain, were also unchanged (Couloigner et al. 1998; Teixeira et al. 1999). No specific enzyme activity was found in the guinea pig ES using a cytochemical technique (Albers et al. 1991). Likewise, low levels of $\mathrm{Na} / \mathrm{K}$-ATPase with co-existence of $\mathrm{Ca}^{2+}$-ATPase and calcium-binding proteins were restricted to the intermediate and distal portions of the ES with no $\beta 2$ subunits, compared with the rest of the inner ear (Ichimiya et al. 1994). A low Na/

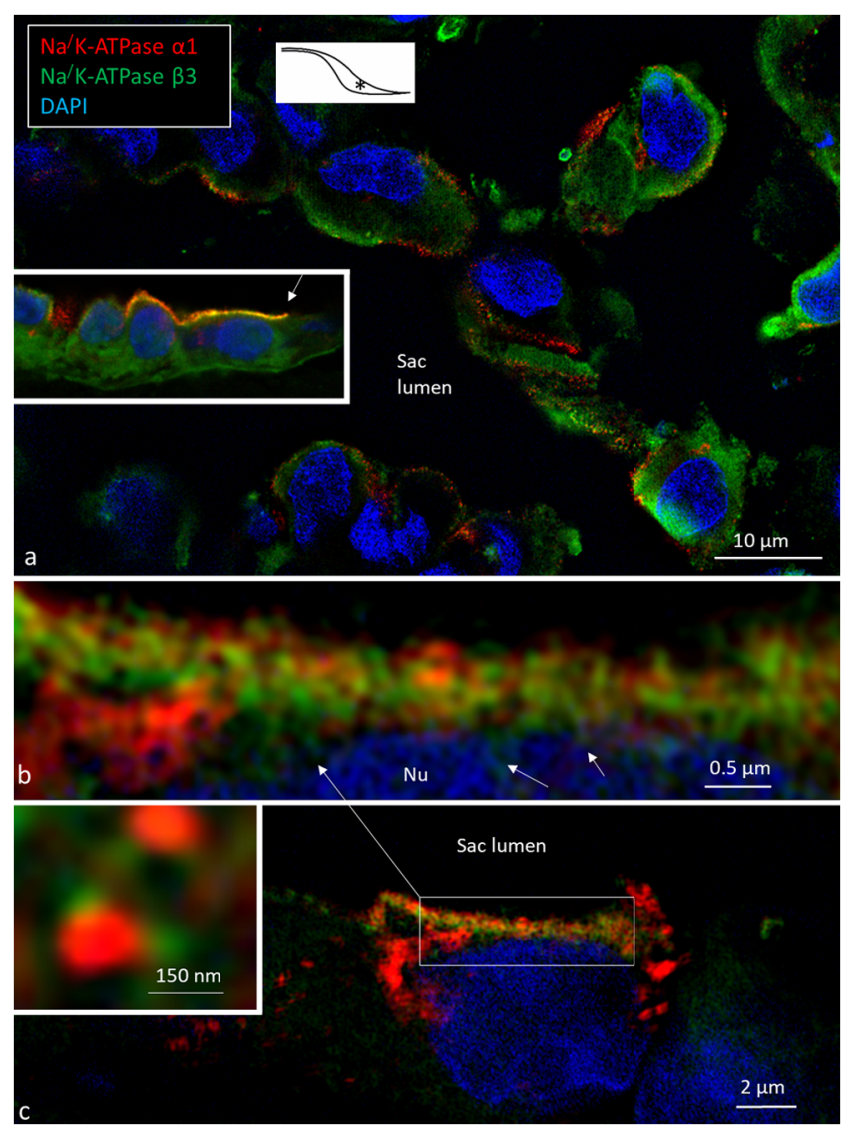

Fig. 6 SR-SIM (single optical section) of human ES (intermediate portion). Inset showing level of sectioning (*) of the ES. Expression of $\mathrm{Na} / \mathrm{K}$-ATPase $\alpha 1$ and $\beta 3$ isoforms (a). There is strong co-labeling at the apical cell membrane in some epithelial cells (arrow at inset). High magnification of the apical cell membrane in a cell displayed in the framed area in $\mathrm{c}(\mathrm{b})$. The $\beta 3$ isoform is also expressed in the cell nucleus (arrows) and apical cytoplasm near the cell membrane. Inset in c shows nanoscopic resolution of ion transporter isoforms in the apical cell membrane

K-ATPase activity could be consistent with the decrease in mRNA ENaC subunits found early, suggesting that $\mathrm{Na}^{+}$reabsorption in the ES occurs mostly during development (Gründer et al. 2001). However, laser capture microdissection, RT-PCR, and immunohistochemistry verified $\mathrm{Na}^{+}$-selective channels in mature ES epithelia (Mori and Wu 1996) that co-localized apically with the $\mathrm{Cl}^{-}$channel cystic fibrosis transmembrane conductance regulator (CFTR) (Matsubara et al. 2014).

Additional ion transport systems identified in the mature $\mathrm{ES}$, such as $\mathrm{K}^{+}$conductance channels (Wu and Mori 1996), vacuolar-type $\mathrm{H}^{+}$-ATPase (Stanković et al. 1997), $\mathrm{Na}^{+} / \mathrm{H}^{+}$exchanger (NHE) (Wu and Mori 1998), pendrin (SLC26A4) (Dou et al. 2004), $\mathrm{Cl}^{-}$-HCO3 exchanger (SLC4A2) (Stanković et al. 1997), and CA (Takumida et al. 1988, 1989; Tsujikawa et al. 1993), suggested that CA activity is involved in the formation of ES fluid. $\mathrm{Na} / \mathrm{K} / 2 \mathrm{Cl}$ cotransporter 2 (NKCC2) (Akiyama et al. 2007; Nishimura et al. 2009), 


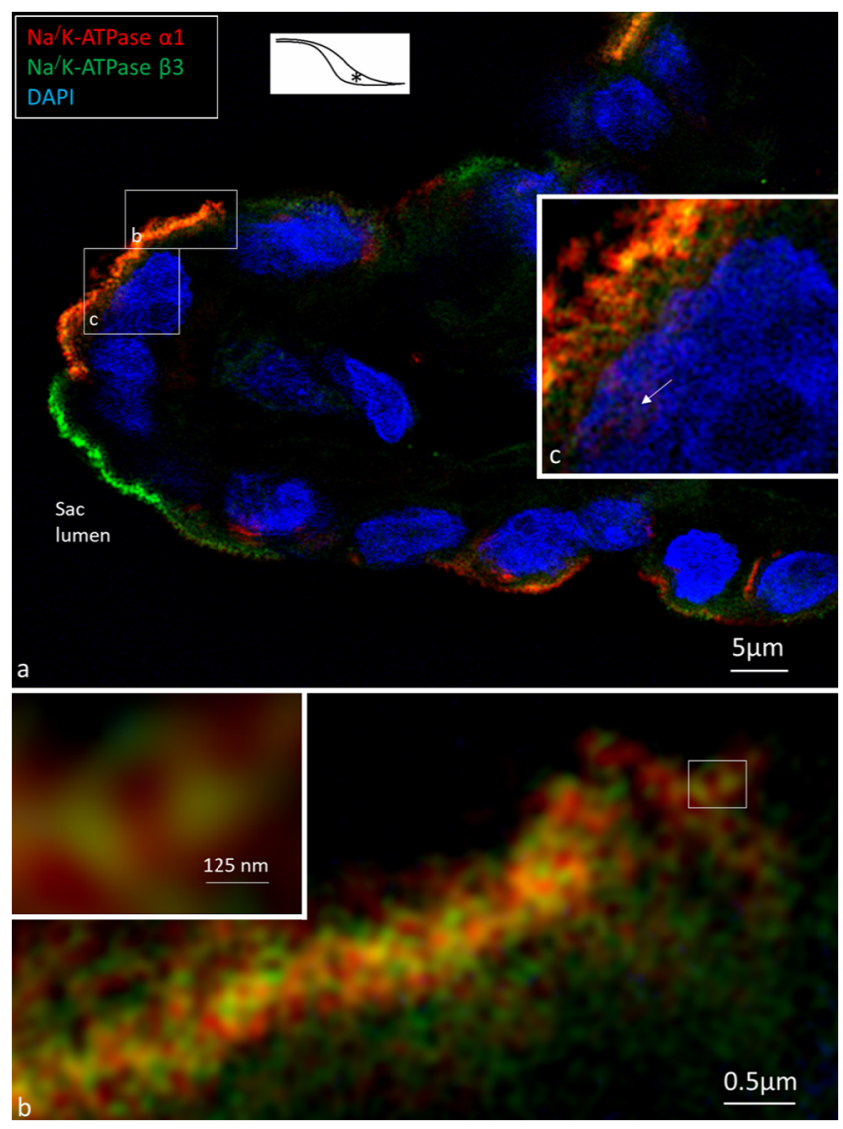

Fig. 7 SR-SIM (single optical section) of an epithelial villus in the intermediate portion of the human ES. Inset showing level of sectioning $\left.{ }^{*}\right)$ of the ES. Epithelial cells co-express $\mathrm{Na} / \mathrm{K}$-ATPase $\alpha 1$ and $\beta 3$ isoforms in the apical cell membrane (a). A neighboring cell expresses only the $\beta 3$ isoform. Inset shows framed area $b$ at higher magnification. The nucleus contains $\alpha 1$ complexes (arrow), while the cytoplasm harbors both isoforms. The apical cell membrane framed (c) in a (b). Both $\alpha 1$ and $\beta 3$ isoforms are expressed in the apical cytoplasm and coalesce in the cell membrane. Inset shows framed area at higher magnification

thiazide-sensitive $\mathrm{Na} / \mathrm{Cl}$ cotransporter (NCC) (Akiyama et al. 2008; Møller et al. 2015), and aquaporin have also been identified (Couloigner et al. 2004; Taguchi et al. 2007). Aldosterone may regulate $\mathrm{Na}^{+}$transport via apical sodium channels, and $\mathrm{Na} / \mathrm{K}$-ATPase may also influence the effect of salt-reduced diet treatment in Meniere's disease. Couloigner injected diuretics locally, such as $\mathrm{Na} / \mathrm{K} / 2 \mathrm{CI}$ and $\mathrm{Na}-\mathrm{Cl}$ cotransporter inhibitors which failed to alter the ESP (Couloigner et al. 1998). They found that locally applied diuretics, such as acetazolamide and amiloride, acting in acidbase transports, are essential for the ESP. They recommended further studies on their influence on endolymph homeostasis for possible future treatments of Meniere's disease (Couloigner et al. 1998).

In the present study, $\mathrm{Na} / \mathrm{K} / 2 \mathrm{Cl}$ cotransporter 2 was expressed together with the thiazide-sensitive $\mathrm{Na} / \mathrm{Cl}$ cotransporter (NCC) as well as ENaC. Notably, valuable information has been provided from embryological studies and endolymphatic space development. Single-cell RNA analyses demonstrated transcriptomes in the MRCs, suggesting their role in "vectorial" ion transport (Honda et al. 2017). Cells showed a high activity of $\mathrm{Na} / \mathrm{K}$-ATPase and $\mathrm{Na}^{+}$permeability. Absorption depended on SLC26A4 with the combined action of $\mathrm{Na} / \mathrm{K}$-ATPase and $\mathrm{K}^{+}$channels in the basolateral membrane and $\mathrm{Na}^{+}$permeable channels in the apical membrane (Akiyama et al. 2008; Kim and Wangemann 2010; Li et al. 2013; Honda et al. 2017).

\section{“Reversed polarity" of $\mathrm{Na} / \mathrm{K}$-ATPase expression}

Remarkably, Na/K-ATPase $\alpha 1 \beta 3$ heterodimers were localized in the apical cell membrane in some epithelial cells. Such "reversed polarity" has been described previously in the eye, choroid plexus, prostate, lacrimal gland, umbilical endothelial cells, and malignant cells with an isoform combination of $\alpha 1 \beta 3$ and is associated with a reversed fluid transfer (Wood and Mircheff 1986; Gundersen et al. 1991; Blanco 2005; Pierre and Xie 2006). The choroid plexus secretes cerebrospinal fluid (CSF) with $\mathrm{Na} / \mathrm{K}$-ATPase, $\mathrm{K}^{+}$channels, $\mathrm{Cl} /$ $\mathrm{HCO}^{-}$exchangers, $\mathrm{Na} / 2 \mathrm{Cl} / \mathrm{K}$ cotransporters, and a variety of $\mathrm{Na}^{+}$-coupled $\mathrm{HCO}^{-}$transporters involved (Brown et al. 2004). We also found antibody labeling of the $\alpha 1$ subunit in the apical cell membrane in the guinea pig choroid plexus. The $\alpha 1 \beta 3$ polarity in the human ES seems to validate earlier outcomes indicating that the ES also has a secretory capability (Erwall et al. 1988, 1989; Jansson and Rask-Andersen 1992). The $\alpha 1$ subunit was expressed in $40 \%$ of the epithelial cells suggesting that the ES may have a considerable secretory capability. However, the ubiquitous $\beta 1$ subunit was expressed basolateral in $78 \%$ of the cells. Some of these cells did not have the typical cylindrical shape. Nonetheless, the findings may be indicative of a considerable absorptive potential of many ES epithelial cells.

\section{Can surgery initiate ES secretion?}

SR-SIM showed, surprisingly, that some cells expressed only the $\beta 3$ subunit in the apical plasma membrane without the $\alpha 1$ subunit. Both proteins appeared individually in the cytoplasm, suggesting an independent transfer to the plasma membrane. The $\beta$ subunit is believed to serve as a molecular chaperone for the $\alpha$ subunit and is required for its folding and processing in the Golgi to avoid degradation (Geering 2001). Subunits are synthesized by ribosomes on the endoplasmic reticulum membrane and undergo packing by disulfide bonds. Both subunits may be inserted independently into the endoplasmic reticulum and associate after glycosylation of the $\beta$ subunit (Gundersen et al. 1991). The $\mathrm{Na} / \mathrm{K}$-ATPase $\alpha$ subunit exits from the endoplasmic reticulum and passes to the cell surface under the regulation of the $\beta$ subunit. The time required for $\mathrm{Na} / \mathrm{K}$ ATPase to arrive at the cell surface after synthesis has been 
Fig. 8 Confocal microscopy of the intermediate human ES showing expression of $\mathrm{Na} / \mathrm{K}$ ATPase $\beta 1$ and NKCC2 (a). Many NKCC2-positive cells lack ATPase expression. Mineral corticoid receptor expression in the ES (b). Both Na/K-ATPase-positive and negative cells are positive. SR-SIM showing heavy activity of $\mathrm{Na} / \mathrm{K}$-ATPase in the basolateral plasma membrane (filled arrow) and NKCC2 positivity (c). Confocal microscopy show expression of NCC and $\mathrm{ENaC}(\mathrm{d}, \mathrm{e})$
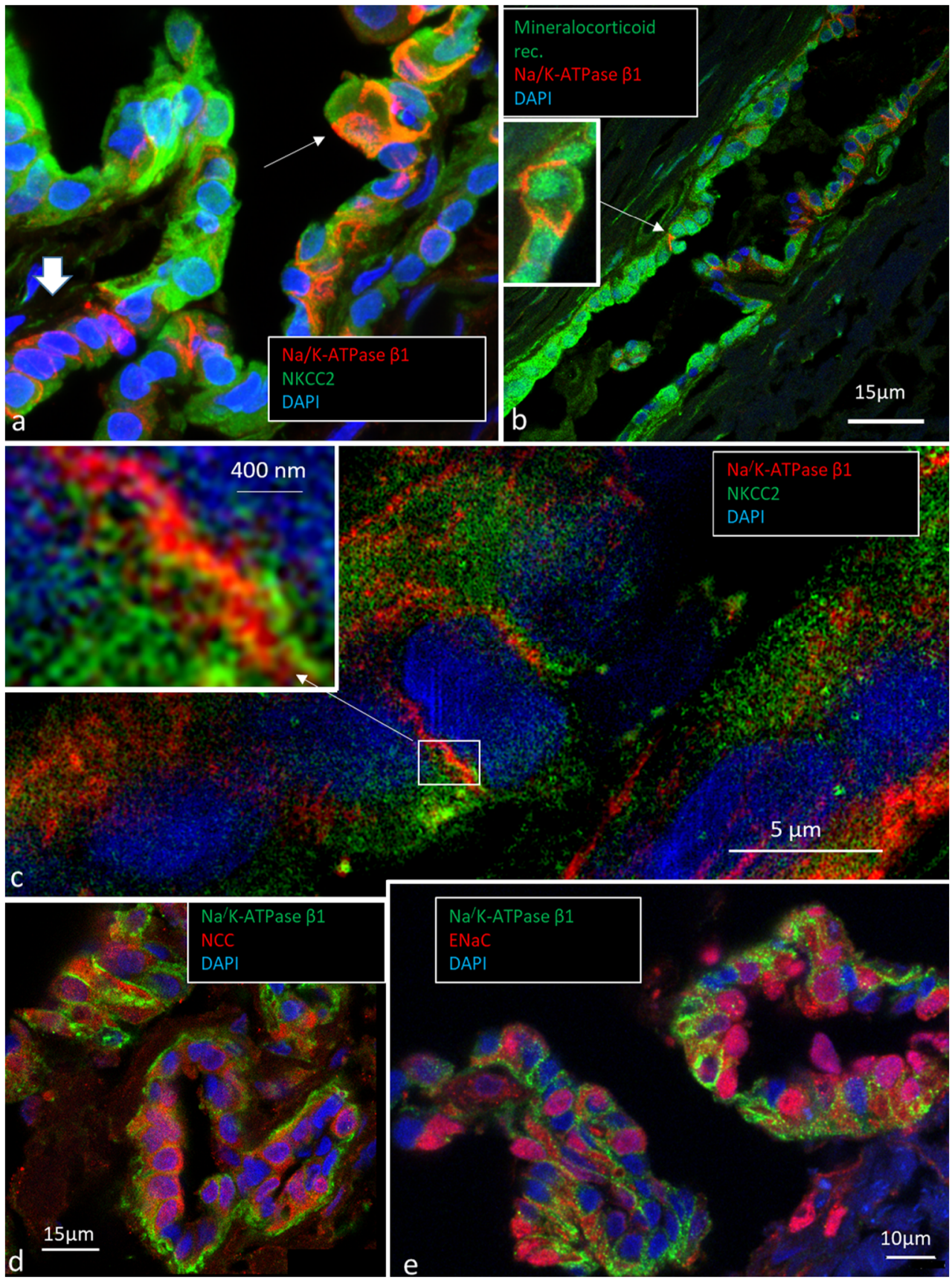

estimated to be approximately $50 \mathrm{~min}$ with mandatory processing for its catalytic function before its arrival at the cell surface (Caplan et al. 1990). The $\beta$ subunit may reach the plasma membrane without interacting with the $\alpha$ subunit. The reversal of the ankyrin/fodrin sub-membrane cytoskeleton is thought to be responsible for the polarized distribution of the $\mathrm{Na} / \mathrm{K}$-ATPase (Gundersen et al. 1991) via an interaction with the $\alpha$ subunit of $\mathrm{Na} / \mathrm{K}$-ATPase protein (Nelson and Veshnock 1987; Morrow et al. 1989; Wetzel et al. 1999). An intriguing explanation for the solitary $\beta 3$ incorporation in the apical plasma membrane (Fig. 5a) may be the swift transcription and migration of $\beta$ subunit mRNAs triggered by inner ear surgery. Labyrinth ablation reduces fluid pressure $1-2 \mathrm{~h}$ before collecting the tissue, and in the meantime, the expression of pre-existing $\mathrm{Na}^{+}$pumps via aldosterone or other instruments (Feraille and Dizin 2016) could increase in an attempt to restore fluid pressure.

\section{Is the $\mathrm{Na} / \mathrm{K}$-ATPase pump responsible for initiating longitudinal endolymph outflow?}

Experimental studies provide little evidence of an endolymph "flow" (Salt and DeMott 1997), a situation possibly altered under stress and various physiological demands (Rask- 
Polarized Expression of $\mathrm{Na}^{+} / \mathrm{K}^{+}$-ATPase in the Human Endolymphatic Sac
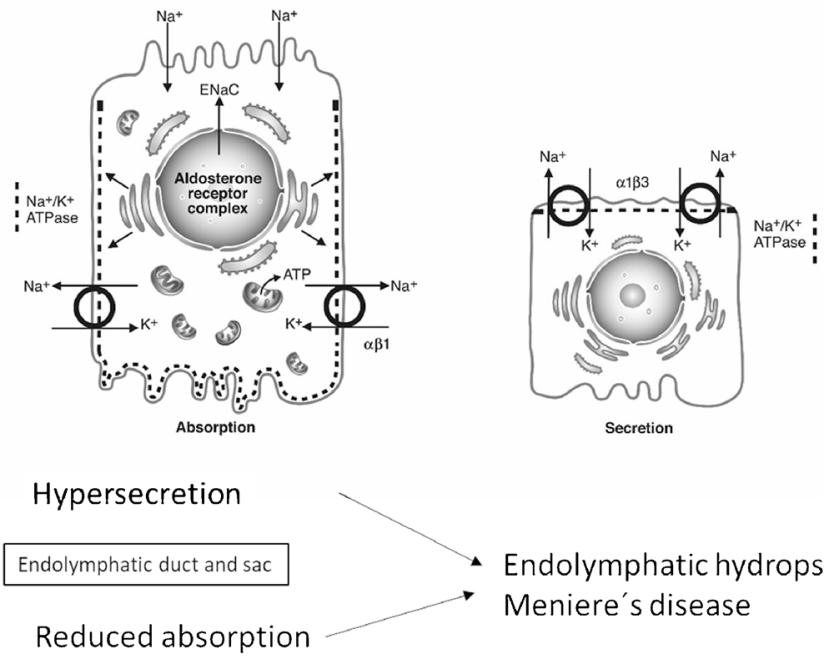

Fig. 9 Proposed implication of a "reversed polarization" of Na/K-ATPase isoform expression in the epithelium of the human ES. Cylindrical cells (left) express $\alpha \beta 1$ in the basolateral membrane, while the right cell expresses $\alpha 1 \beta 3$ in the apical plasma membrane. $\mathrm{A}$ high $\mathrm{Na}^{+}$conductance in the apical plasma membrane is due to the presence of amiloride-sensitive $\mathrm{Na}^{+}$channels (Kim et al. 2009). $\mathrm{Na}^{+}$channels and $\mathrm{Na} / \mathrm{K}$-ATPase may be controlled by the hormone aldosterone (Furuta et al. 1999; Akiyama et al. 2010). It may also activate apical and basolateral $\mathrm{K}^{+}$channels (Mori and Wu 1996; Wu and Mori 1996; Kim et al. 2015). A thiazide-sensitive Na/ $\mathrm{Cl}$ cotransporter was also detected in the apical membrane by Akiyama et al. (Akiyama et al. 2008)

Andersen et al. 1999). A trans-cellular transport of ions is consistent with observations of increased tight junction barriers in the distal ES as demonstrated by freeze fracturing, tracer studies, and morphological observations (Rask-Andersen et al. 1981; Friberg et al. 1984b; Hultgård-Ekwall et al. 2003, 2006). Active cellular pumps in the intraosseous ES could induce a longitudinal "syphon" of endolymph (Møller et al. 2013). There are wide intercellular spaces next to the MRCs in the murine ES, indicating an active bulk flow across the epithelium of the ES (Friberg et al. 1985). In man and guinea pig, a gradual para-cellular outflow may ensue already in the ED where tight junctions (TJs) are shallow and the epithelium is surrounded by specialized vascularity (Rask-Andersen et al. 1981; Bagger-Sjöbäck and Rask-Anderson 1986). Larger substances may accrue in the distal ES. This assumption is supported by immune histochemical studies (Ichimiya et al. 1994). The cylindrical and "light" cells may correspond to the MRCs (Erwall et al. 1988; Qvortrup et al. 1999; Møller et al. 2013) and are believed to be involved in fluid absorption (Bagger-Sjöbäck et al. 1986). The saccular endolymph is rich in potassium and low in sodium, and these solutes may equilibrate across the membrane system to the ES. Earlier studies showed that the ES may both absorb and secrete depending on the physiological demands (Rask-Andersen et al. 1999). The present results of a polarized expression of $\mathrm{Na} / \mathrm{K}$-ATPase in the human ES support such an action, and its interpretation is shown in Fig. 9. This may cast new light on the pathophysiology of MD since both a lowered absorption and a hypersecretion could be responsible for the accumulation of fluid and lead to endolymphatic hydrops.

A "polarized" expression of $\mathrm{Na} / \mathrm{K}$-ATPase consistent with both $\mathrm{Na}$ and fluid absorption and secretion in combination with hormone receptors may have implications for the etiology of MD. Intra-tympanic gentamicin is widely used in refractory MD. Notably, intra-tympanic methylprednisolone was recently shown to be as effective (Patel et al. 2016). Glucocorticoids also bind to the human mineralocorticoid receptor that regulates the transcription of the human $\mathrm{Na} / \mathrm{K}$ ATPase (Kolla and Litwack 2000). Furthermore, steroid treatment in MD may modulate the inflammatory response and/or restore endolymph ion balance. The anti-inflammatory effect of glucocorticoids is also linked to the suppression of the transcription factor nuclear factor-kappa beta $(\mathrm{NF}-\mathrm{kB})$ which plays a key role in regulating the immune response. In a recent case-control study (Kolla and Litwack 2000), the authors found a gene locus associated with bilateral MD suggesting that carriers may develop a NF-kB-mediated inflammatory response in MD. Friis et al. (2013) found that the ES of rats that were isoimmunized with an ES extract developed specific tissue alterations identical to those present in the ES of active MD. Those findings support the theory that an immune injury may be important in the pathogenesis in MD. Further studies, in combination with additional ion transporter systems, are necessary to fully understand the organization of this system at the molecular level and how it may relate to disease. Nonetheless, careful interpretation is needed since obtained tissue is derived from patients with benign tumors which could modify the inner ear steady-state conditions.

Acknowledgments We are grateful to SciLife Laboratories and the BioVis Platform at Uppsala University for providing SR-SIM microscope equipment and for personal support throughout the study. This study was partly supported by Medel Inc., Innsbruck, Austria.

Author's contribution $\mathrm{CN}$ performed immunohistochemistry, microscopy, and manuscript writing. WL performed immunohistochemistry and microscopy. ND harvested surgical specimens. HR is the head of laboratory and planned the project, analyzed the images, and wrote the manuscript.

Funding information Open access funding provided by Uppsala University. This study was supported by ALF grants from Uppsala University, Sweden.

\section{Compliance with ethical statements}

Conflict of Interest The authors declare that the research was conducted in the absence of any commercial or financial relationships that could be construed as a potential conflict of interest. Dr. Wei Liu received part salary from the Medel Inc., Innsbruck, Austria.

Informed consent Informed consent was obtained from all individual participants included in this study. 
Ethical approval The study of human discarded materials was approved by the local ethics committee (Etikprövningsnämnden Uppsala, no. 99398, 22/9 1999, cont, 2003, no. C254/4; no. C45/7 2007, Dnr. 2013/190), and informed consent was obtained. All procedures performed in this study involving human participants were in accordance with the ethical standards of the local research committee and with the 1964 Helsinki declaration and its later amendments or comparable ethical standards. Sections of archival guinea pig cochlea were also analyzed; the protocol was approved by the Regional Animal Review Board of Uppsala, Sweden (permit number C98/12 and C66/16). All applicable international, national, and institutional guidelines for the care and use of animals were followed.

Open Access This article is licensed under a Creative Commons Attribution 4.0 International License, which permits use, sharing, adaptation, distribution and reproduction in any medium or format, as long as you give appropriate credit to the original author(s) and the source, provide a link to the Creative Commons licence, and indicate if changes were made. The images or other third party material in this article are included in the article's Creative Commons licence, unless indicated otherwise in a credit line to the material. If material is not included in the article's Creative Commons licence and your intended use is not permitted by statutory regulation or exceeds the permitted use, you will need to obtain permission directly from the copyright holder. To view a copy of this licence, visit http://creativecommons.org/licenses/by/4.0/.

\section{References}

Akiyama K, Miyashita T, Mori T, Mori N (2007) Expression of the Na+$\mathrm{K}+-2 \mathrm{Cl}$ - cotransporter in the rat endolymphatic sac. Biochem Biophys Res Commun 364:913-917

Akiyama K, Miyashita T, Mori T et al (2008) Expression of thiazidesensitive $\mathrm{Na}+\mathrm{Cl}-$ cotransporter in the rat endolymphatic sac. Biochem Biophys Res Commun 371:649-653

Akiyama K, Miyashita T, Matsubara A, Mori N (2010) The detailed localization pattern of $\mathrm{Na}+/ \mathrm{K}+/ 2 \mathrm{Cl}$-cotransporter type 2 and its related ion transport system in the rat endolymphatic sac. J Histochem Cytochem 58:759-763

Albers FWJ, Van Benthem PPG, De Groot JCMJ (1991) Cytochemical localization of ouabain-sensitive, potassium-dependent pnitrophenylphosphatase in the Guinea pig inner ear. Acta Otolaryngol 111:885-890

Amano H, Orsulakova A, Morgenstern C (1983) Intracellular and extracellular ion content of the endolymphatic sac. Arch Otorhinolaryngol 237:273-277

Bagger-Sjöbäck D, Rask-Anderson H (1986) The permeability barrier of the endolymphatic sac. A hypothesis of fluid and electrolyte exchange based on freeze fracturing. Am J Otol 7:134-140

Bagger-Sjöbäck D, Friberg U, Rask-Andersen H (1986) The human endolymphatic sac: an ultrastructural study. Arch Otolaryngol Neck Surg 112:398-409

Bagger-sjöbäck D, Friberg U, Jansson B, Rask-Andersen H (1988) The variational anatomy of the human endolymphatic sac. Acta Otolaryngol 105:187-189

Bauwens LJJM, De Groot JCMJ, Ramaekers FCS et al (1991) Differential immunohistochemical detection of cytokeratins and vimentin in the surgically removed human endolymphatic duct and sac. Eur Arch Oto-Rhino-Laryngol 248:495-501

Blanco G (2005) Na,K-ATPase subunit heterogeneity as a mechanism for tissue-specific ion regulation. Semin Nephrol 25:292-303
Bordin L, Saccardi C, Donà G et al (2016) Mineralocorticoid receptor is involved in the aldosterone pathway in human red blood cells. Am J Transl Res 8:314-328

Brown PD, Davies SL, Speake T, Millar ID (2004) Molecular mechanisms of cerebrospinal fluid production. Neuroscience 129:955-968

Burry RW (2011) Controls for immunocytochemistry: an update. J Histochem Cytochem 59:6-12

Caplan MJ, Forbush B, Palade GE, Jamieson JD (1990) Biosynthesis of the Na,K-ATPase in Madin-Darby canine kidney cells. Activation and cell surface delivery. J Biol Chem 265:3528-3534

Clausen MV, Hilbers F, Poulsen H (2017) The structure and function of the Na,K-ATPase isoforms in health and disease. Front Physiol 8: 371

Couloigner V, Loiseau A, Sterkers O et al (1998) Effect of locally applied drugs on the endolymphatic sac potential. Laryngoscope 108:592598

Couloigner V, Berrebi D, Teixeira M et al (2004) Aquaporin-2 in the human endolymphatic sac. Acta Otolaryngol 124:449-453

Crambert G, Hasler U, Beggah AT et al (2000) Transport and pharmacological properties of nine different human $\mathrm{Na}, \mathrm{K}$-ATPase isozymes. J Biol Chem 275:1976-1986

Dahlmann A, von Düring M (1995) The endolymphatic duct and sac of the rat: a histological, ultrastructural, and immunocytochemical investigation. Cell Tissue Res 282:277-289

Dou H, Xu J, Wang Z et al (2004) Co-expression of pendrin, vacuolar $\mathrm{H}+$-ATPase $\alpha 4$-subunit and carbonic anhydrase II in epithelial cells of the murine endolymphatic sac. J Histochem Cytochem 52:13771384

Erwall C, Jansson B, Friberg U, Rask-Andersen H (1988) Subcellular changes in the endolymphatic sac after administration of hyperosmolar substances. Hear Res 35:109-118

Erwall C, Takumida M, Bagger-Sjöbäck D et al (1989) Uptake of radioactive sulphur in the endolymphatic sac: an autoradiographic study. Acta Otolaryngol 107:63-70

Feraille E, Dizin E (2016) Coordinated control of ENaC and $\mathrm{Na}+, \mathrm{K}+-$ ATPase in renal collecting duct. J Am Soc Nephrol 27:2554-2563

Fina M, Ryan A (1994) Expression of mrnas encoding $\alpha$ and $\beta$ subunit isoforms of na, k-atpase in the vestibular labyrinth and endolymphatic sac of the rat. Mol Cell Neurosci 5:604-613

Friberg U, Rask-Andersen H, Bagger-Sjoback D (1984a) The human endolymphatic duct and sac. Acta Otolaryngol 98:115-116

Friberg U, Rask-Andersen H, Bagger-Sjöbäck D (1984b) Human endolymphatic duct: an ultrastructural study. Arch Otolaryngol 110:421428

Friberg U, Bagger-Sjöbäck D, Rask-Andersen H (1985) The lateral intercellular spaces in the endolymphatic sac. A pathway for fluid transport? Acta Otolaryngol 100:3-17

Friis M, Thomsen A, Poulsen S et al (2013) Experimental hyperactivity of the endolymphatic sac. Audiol Neurotol 18:125-133

Furuta H, Sato C, Kawaguchi Y et al (1999) Expression of mRNAs encoding hormone receptors in the endolymphatic sac of the rat. Acta Otolaryngol 119:53-57

Geering K (2001) The functional role of $\beta$ subunits in oligomeric P-type ATPases. J Bioenerg Biomembr 33:425-438

Geering K (2008) Functional roles of Na,K-ATPase subunits. Curr Opin Nephrol Hypertens 17:526-532

Gründer S, Müller A, Peter Ruppersberg J (2001) Developmental and cellular expression pattern of epithelial sodium channel $\alpha, \beta$ and $\gamma$ subunits in the inner ear of the rat. Eur J Neurosci 13:641-648

Gundersen D, Orlowski J, Rodriguez-Boulan E (1991) Apical polarity of $\mathrm{Na}, \mathrm{K}-\mathrm{ATP}$ ase in retinal pigment epithelium is linked to a reversal of the ankyrin-fodrin submembrane cytoskeleton. J Cell Biol 112:863872

Gustafsson MG, Shao L, Carlton PM et al (2008) Three-dimensional resolution doubling in wide-field fluorescence microscopy by structured illumination. Biophys J 94:4957-4970 
Hampel P, Römermann K, MacAulay N, Löscher W (2018) Azosemide is more potent than bumetanide and various other loop diuretics to inhibit the sodium-potassium-chloride-cotransporter human variants hNKCC1A and hNKCC1B. Sci Rep 8:9877

Hasler U, Wang X, Crambert G et al (1998) Role of $\beta$-subunit domains in the assembly, stable expression, intracellular routing, and functional properties of Na,K-ATPase. J Biol Chem 273:30826-30835

Hell SW, Wichmann J (1994) Breaking the diffraction resolution limit by stimulated emission: stimulated-emission-depletion fluorescence microscopy. Opt Lett 19:780

Honda K, Kim SH, Kelly MC et al (2017) Molecular architecture underlying fluid absorption by the developing inner ear. Elife 6

Hultgård-Ekwall AKH, Couloigner V, Rubin K, Rask-Andersen H (2003) Network organization of interstitial connective tissue cells in the human endolymphatic duct. J Histochem Cytochem 51:1491-1500

Hultgard-Ekwall AK, Mayerl C, Rubin K et al (2006) An interstitial network of podoplanin-expressing cells in the human endolymphatic duct. J Assoc Res Otolaryngol 7:38-47

Ichimiya I, Adams JC, Kimura RS (1994) Immunolocalization of na+, k+-ATPase, ca+plus;-ATPase, calcium-binding proteins, and carbonic anhydrase in the guinea pig inner ear. Acta Otolaryngol 114: $167-176$

Ivakine EA, Acton BA, Mahadevan V et al (2013) Neto2 is a KCC2 interacting protein required for neuronal $\mathrm{Cl}$ - regulation in hippocampal neurons. Proc Natl Acad Sci U S A 110:3561-3566

Jansson B, Rask-Andersen H (1992) Osmotically induced macrophage activity in the endolymphatic sac: on the possible interaction between periaqueductal bone marrow cells and the endolymphatic sac. ORL 54:191-197

Jansson B, Friberg U, Rask-Andersen H (1992) Effects of glycerol on the endolymphatic sac: a time-sequence study. Orl 54:201-210

Jia C-E, Jiang D, Dai H et al (2016) Pendrin, an anion exchanger on lung epithelial cells, could be a novel target for lipopolysaccharideinduced acute lung injury mice. Am J Transl Res 8:981-992

Kakigi A, Nishimura M, Takeda T et al (2009) Expression of aquaporin1, 3 , and 4, NKCC1, and NKCC2 in the human endolymphatic sac. Auris Nasus Larynx 36:135-139

Kämpfe Nordström C, Danckwardt-Lillieström N, Laurell G et al (2018) The human endolymphatic sac and inner ear immunity: macrophage interaction and molecular expression. Front Immunol 9:3181

Kim HM, Wangemann P (2010) Failure of fluid absorption in the endolymphatic sac initiates cochlear enlargement that leads to deafness in mice lacking pendrin expression. PLoS One 5:e14041

Kim SH, Park HY, Choi HS et al (2009) Functional and molecular expression of epithelial sodium channels in cultured human endolymphatic sac epithelial cells. Otol Neurotol 30:529-534

Kim SH, Kim BG, Kim JY et al (2015) Electrogenic transport and K + ion channel expression by the human endolymphatic sac epithelium. Sci Rep 5:18110

Kimura RS (1967) LII. Experimental blockage of the endolymphatic duct and sac and its effect on the inner ear of the guinea pig: a study on endolymphatic hydrops. Ann Otol Rhinol Laryngol 76:664-687

Kimura RS, Schuknecht HF (1965) Membranous hydrops in the inner ear of the guinea pig after obliteration of the endolymphatic sac. Pr otorhino-laryng 27:343-354

Kolla V, Litwack G (2000) Transcriptional regulation of the human $\mathrm{Na} / \mathrm{K}$ ATPase via the human mineralocorticoid receptor. Mol Cell Biochem 204:35-40

Kumagami H, Tanaka F, Dotsu M et al (2004) Measurement of the endolymphatic sac potential in human. Hear Res 193:20-24

Lee HJ, Yang WS, Park HW et al (2012) Expression of anion exchangers in cultured human endolymphatic sac epithelia. Otol Neurotol 33: 1664-1671

Li X, Zhou F, Marcus DC, Wangemann P (2013) Endolymphatic Na+ and $\mathrm{K}+$ concentrations during cochlear growth and enlargement in mice lacking Slc26a4/pendrin. PLoS One 8:e1003641
Li Y, Chang J, Cui Y et al (2017) Novel mechanisms for crotonaldehydeinduced lung edema. Oncotarget 8:83509-83522

Liu W, Boström M, Kinnefors A, Rask-Andersen H (2009) Unique expression of connexins in the human cochlea. Hear Res 250:55-62

Liu W, Schrott-Fischer A, Glueckert R et al (2017) The Human "cochlear battery" - claudin-11 barrier and ion transport proteins in the lateral wall of the cochlea. Front Mol Neurosci 10:239

Lundquist PG, Kimura R, Wersaell J (1964) Experiments in endolymph circulation. Acta Otolaryngol Suppl 188(SUPPL 188):198

Matsubara A, Miyashita T, Inamoto R et al (2014) Cystic fibrosis transmembrane conductance regulator in the endolymphatic sac of the rat. Auris Nasus Larynx 41:409-412

Miyashita T, Tatsumi H, Hayakawa K et al (2007) Large $\mathrm{Na(+)}$ influx and high $\mathrm{Na}(+), \mathrm{K}(+)$-ATPase activity in mitochondria-rich epithelial cells of the inner ear endolymphatic sac. Pflugers Arch 453:905-913

Miyashita T, Akiyama K, Inamoto R et al (2012) Presence of FXYD6 in the endolymphatic sac epithelia. Neurosci Lett 513:47-50

Møller MN, Caye-Thomasen P, Qvortrup K (2013) Oxygenated fixation demonstrates novel and improved ultrastructural features of the human endolymphatic sac. Laryngoscope 123:1967-1975

Møller MN, Kirkeby S, Vikeså J et al (2015) Gene expression in the human endolymphatic sac: the solute carrier molecules in endolymphatic fluid homeostasis. Otol Neurotol 36:915-922

Mori N, Wu DZ (1996) Low-amiloride-affinity Na+channel in the epithelial cells isolated from the endolymphatic sac of guinea-pigs. Pflugers Arch Eur J Physiol 433:58-64

Mori N, Miyashita T, Inamoto R et al (2017) Ion transport its regulation in the endolymphatic sac: suggestions for clinical aspects of Meniere's disease. Eur Arch Otorhinolaryngol 274:1813-1820

Morrow JS, Cianci CD, Ardito T et al (1989) Ankyrin links fodrin to the alpha subunit of $\mathrm{Na}, \mathrm{K}-\mathrm{ATPase}$ in Madin-Darby canine kidney cells and in intact renal tubule cells. J Cell Biol 108:455-465

Nelson WJ, Veshnock PJ (1987) Ankyrin binding to (Na++K+)ATPase and implications for the organization of membrane domains in polarized cells. Nature 328:533-536

Nishimura M, Kakigi A, Takeda T et al (2009) Expression of aquaporins, vasopressin type 2 receptor, and $\mathrm{Na}+-\mathrm{K}+-\mathrm{Cl}$ - cotransporters in the rat endolymphatic sac. Acta Otolaryngol 129:812-818

Park H (2003) Origins and frequencies of SLC26A4 (PDS) mutations in east and south Asians: global implications for the epidemiology of deafness. J Med Genet 40:242-248

Patel M, Agarwal K, Arshad Q et al (2016) Intratympanic methylprednisolone versus gentamicin in patients with unilateral Ménière's disease: a randomised, double-blind, comparative effectiveness trial. Lancet 388:2753-2762

Peters TA, Kuijpers W, Curfs JHAJ (2001) Occurrence of NaK-ATPase isoforms during rat inner ear development and functional implications. Eur Arch Oto-Rhino-Laryngol 258:67-73

Pierre SV, Xie Z (2006) The Na,K-ATPase receptor complex: its organization and membership. Cell Biochem Biophys 46:303-315

Qvortrup K, Rostgaard J, Holstein-Rathlou NH, Bretlau P (1999) The endolymphatic sac, a potential endocrine gland? Acta Otolaryngol 119:194-199

Raft S, Andrade LR, Shao D et al (2014) Ephrin-B2 governs morphogenesis of endolymphatic sac and duct epithelia in the mouse inner ear. Dev Biol 390:51-67

Rask-Andersen H, Bredberg G, Lyttkens L, Loof G (1981) The function of the endolymphatic duct-an experimental study using ionic lanthanum as a tracer: a preliminary report. Ann N Y Acad Sci 374:1119

Rask-andersen H, Danckwardt-lillieström N, Friberg U, House W (1991) Lymphocyte-macrophage activity in the human endolymphatic sac. Acta Otolaryngol 111:15-17

Rask-Andersen H, DeMott JE, Bagger-Sjöbäck D, Salt AN (1999) Morphological changes of the endolymphatic sac induced by 
microinjection of artificial endolymph into the cochlea. Hear Res 138:81-90

Ren Q, Gliozzi ML, Rittenhouse NL, et al (2019) Shear stress and oxygen availability drive differential changes in OK proximal tubule cell metabolism and endocytosis. Traffic tra. 12648

Ruiz-Ederra J, Zhang H, Verkman AS (2007) Evidence against functional interaction between aquaporin-4 water channels and Kir4.1 potassium channels in retinal Müller cells. J Biol Chem 282:21866-21872

Salt AN, DeMott J (1997) Longitudinal endolymph flow associated with acute volume increase in the guinea pig cochlea. Hear Res 107:29 40

Salt AN, DeMott JE (2000) Ionic and potential changes of the endolymphatic sac induced by endolymph volume changes. Hear Res 149: $46-54$

Stanković KM, Brown D, Alper SL, Adams JC (1997) Localization of pH regulating proteins $\mathrm{H}+\mathrm{ATPase}$ and $\mathrm{Cl}-\mathrm{HCO} 3$ - exchanger in the guinea pig inner ear. Hear Res 114:21-34

Taguchi D, Takeda T, Kakigi A et al (2007) Expressions of aquaporin-2, vasopressin type 2 receptor, transient receptor potential channel vanilloid (TRPV)1, and TRPV4 in the human endolymphatic sac. Laryngoscope 117:695-698

Takumida M, Begger-Sjöxbäck D, Rask-Andersen H (1988) Ultrastructural localization of carbonic anhydrase and its possible role in the endolymphatic sac. ORL 50:170-175

Takumida M, Bagger-Sjöbäck D, Rask-Andersern H (1989) Effect of acetazolamide (diamox $\left.{ }^{\circledR}\right)$ on the endolymphatic sac. ORL 51: 276-284

Teixeira M, Couloigner V, Loiseau A et al (1999) Evidence for apical K conductance and $\mathrm{Na}-\mathrm{K}-2 \mathrm{Cl}$ cotransport in the endolymphatic sac of guinea pig. Hear Res 128:45-50

ten Cate WJ, Curtis LM, Rarey KE (1994) Na,K-ATPase subunit isoform expression in the guinea pig endolymphatic sac. ORL J Otorhinolaryngol Relat Spec 56:257-262

Tsujikawa S, Yamashita T, Tomoda K et al (1993) Effects of acetazolamide on acid-base balance in the endolymphatic sac of the guinea pig. Acta Otolaryngol 113:50-53
Weber PC, Cunningham CD, Schulte BA (2001) Potassium recycling pathways in the human cochlea. Laryngoscope 111:1156-1165

Wetzel RK, Arystarkhova E, Sweadner KJ (1999) Cellular and subcellular specification of $\mathrm{Na}, \mathrm{K}$-ATPase $\alpha$ and $\beta$ isoforms in the postnatal development of mouse retina. J Neurosci 19:9878-9889

Wood RL, Mircheff AK (1986) Apical and basal-lateral Na/K-ATPase in rat lacrimal gland acinar cells. Invest Ophthalmol Vis Sci 27:12931296

Wu D, Mori N (1996) Outward K+ current in epithelial cells isolated from intermediate portion of endolymphatic sac of guinea pigs. Am J Phys 271:C1765-C1773

Wu DZ, Mori N (1998) Evidence for the presence of a Na+-H+exchanger in the endolymphatic sac epithelium of guinea-pigs. Pflugers Arch Eur J Physiol 436:182-188

Wyckelsma VL, Levinger I, Murphy RM, et al (2017) Intense interval training in healthy older adults increases skeletal muscle $[3 \mathrm{H}]$ ouabain-binding site content and elevates $\mathrm{Na}+\mathrm{K}+\mathrm{ATPase} \alpha 2$ isoform abundance in type II fibers. Physiol Rep

Xie JX, Li X, Xie Z (2013) Regulation of renal function and structure by the signaling Na/K-ATPase. IUBMB Life 65:991-998

Yamane H, Nakai Y (1988) Immunohistochemical localization of Na+$\mathrm{K}+$-ATPase in the endolymphatic sac. Adv Otorhinolaryngol 42: $123-128$

Yamashita K, Hatou S, Inagaki E et al (2018) A rabbit corneal endothelial dysfunction model using endothelial-mesenchymal transformed cells. Sci Rep 8:16868

Yang C-R, Tongyoo P, Emamian M et al (2015) Deep proteomic profiling of vasopressin-sensitive collecting duct cells. I. Virtual western blots and molecular weight distributions. Am J Physiol Physiol 309: C785-C798

Publisher's note Springer Nature remains neutral with regard to jurisdictional claims in published maps and institutional affiliations. 